Research Article

\title{
An Essay on Corporate Crimes in the Post-Colonial Perspective: Challenging Traditional Literature
}

\author{
Um Ensaio sobre Crimes Corporativos na Perspectiva Pós-Colonial: \\ Desafiando a Literatura Tradicional
}

\begin{abstract}
Cintia Rodrigues de Oliveira ${ }^{1 \odot}$ Rafael Alcadipani da Silveira ${ }^{2}$
\end{abstract}

\section{ABSTRACT}

Objective: this essay aims to theoretically challenge the notions of corporate crimes developed in traditional literature, which understand this phenomenon as a social and organizational dysfunction, focusing on its antecedents and determinants. Argument: the basic premise of the essay is that corporate crimes occur in a corporate dynamic, the main force of contemporary capitalism over the world. We use the post-colonial thinking, more specifically the concepts of necrocapitalism, a version of contemporary capitalism characterized by imperialism, which refers to contemporary forms of accumulation, which involve the subjugation of life to the power of death. Results: corporate crimes occur on a lasting basis in contexts of extremely complex interrelationships, including relationships between corporations and governments. Conclusions: we conclude that it is necessary to argue against the normalization of corporate crimes in the field of organizational studies, when treating them as a dysfunction. Corporate crimes are configured in a chain of agents, including the state, involving a set of violations that attack nations.

Keywords: corporate crime; necrocapitalism; death.

\section{RESUMO}

Objetivo: este ensaio tem por objetivo desafiar, teoricamente, as noçóes de crimes corporativos desenvolvidas na literatura tradicional, a qual compreende esse fenômeno como uma disfunçáo social e organizacional, concentrando-se nos seus antecedentes e determinantes. Argumento do Ensaio: a premissa básica do ensaio é que crimes corporativos ocorrem em uma dinâmica própria das corporaçóes, a principal força do capitalismo contemporâneo sobre o mundo. Nós recorremos ao pensamento póscolonial, mais especificamente aos conceitos de necrocapitalismo, uma versão do capitalismo contemporâneo caracterizada pelo imperialismo, que se refere a formas contemporâneas de acumulaçáo, as quais envolvem a subjugação da vida ao poder da morte. Resultados: crimes corporativos ocorrem de forma duradoura em contextos de inter-relacionamentos extremamente complexos, incluindo relações entre corporações e governos. Conclusóes: concluímos ser necessário argumentar contra a normalizaçáo dos crimes corporativos no campo dos estudos organizacionais, ao tratálos como uma disfunção. Os crimes corporativos são configurados em uma cadeia de agentes, incluindo o Estado, envolvendo um conjunto de violaçóes que atentam contra naçôes.

Palavras-chave: crimes corporativos; necrocapitalismo; mortes.
1. Universidade Federal de Uberlândia, Faculdade de Gestão e Negócios, Uberlândia, MG, Brazil. 2. Fundação Getulio Vargas, Escola de Administração de Empresas de São Paulo, São Paulo, SP, Brazil.

Cite as: Oliveira, C. R. de, \& Silveira, R. A. da. (2021). An essay on corporate crimes in the post-colonial perspective: Challenging traditional literature. Revista de Administração Contemporânea, 25(4), el 190144. https://doi.org/10.1590/1982-7849rac2021190144.en
JEL Code: F54, D21, P1. Editor-in-chief: Wesley Mendes-Da-Silva (Fundação Getulio Vargas, EAESP, Brazill) Reviewers: Carlos Denner dos Santos Jr (Universidade de Brasília, Brazil) One of the reviewers chose not to disclose his/her identity. Peer Review Report: The Peer Review Report is available at this external URL. Received: April 16, 2019 Last version received: July 15,2020 Accepted: July 20, 2020

\begin{tabular}{|c|c|c|c|c|c|c|c|c|c|}
\hline & 1 & 2 & 3 & 4 & 5 & 6 & 7 & 8 & 9 \\
\hline $1^{\text {st }}$ round & (x) & (x) & 2 & (x) & (x) & (x) & 电 & (x) & \\
\hline $2^{\text {nd }}$ round & $\frac{6}{8}$ & & & & & & & & \\
\hline $3^{\text {rd }}$ round & $\stackrel{8}{2}$ & & & & & & & & \\
\hline
\end{tabular}




\section{INTRODUCTION}

Corporations represent capitalism's main power over the world. Their power has no boundaries: they influence policies and actions in nations, regions, and local communities (Key \& Malnight, 2010; Sklair, 2002), and establish themselves as private tyrannies, as Chomsky (2005) refers to them. In contrast with Berle and Means (1932) definition, Drucker (1993) defines corporations as economic and social entities that operate 'big businesses' in a 'free enterprise' system. They enable the development of large-scale operations within transport, communications, distribution, and production industries, which demand large amounts of capital (Carey, 2011).

Corporations are present everywhere and in almost every aspect of our lives and work. However, corporations are dangerous to society because they commit serious corporate crimes against consumers, workers, the environment, communities, and countries. Furthermore, corporate financial crimes are committed by legitimate businesses that operate in lawful and transnational markets (Lord, Wingerde, \& Campbell, 2018). Global capitalism is supported by transnational practices, which "transcend the geographic boundaries of states but do not necessarily originate from state-owned agencies or players" (Sklair, 2009, p. 498). These practices operate in the economic, political, and cultural-ideological dimensions.

Crimes committed by corporations - such as environmental offenses, corruption, slave labor, and global epistemicide - are part of social structures; therefore, they are subject to influences and articulations in the social, ideological, and institutional context in which they occur. Thus, corporate crimes are a relevant topic for investigation in organizational research.

Transnational corporations are companies globally integrated and politically organized by a transnational capitalist class. They have their roots in the United States of America but they have spread around the world with the support of structured technical and social relationships with mass media, which has efficiently disseminated a cultural ideology of global consumerism (Sklair, 2012a, 2012b).

Global outsourcing and mobility of capital are means for transnational corporations to obtain benefits, such as tax and regulatory incentives and cheaper workforce. These corporations have global supply chains, which can be changed according to their interests. They have power over specialized service providers and can separate subsidiary companies from legal entities to reduce the parent company's financial and legal risks (Antonio \& Bonanno, 2012).

Snider (2020) discussed the nature and scope of resistance of movements (labor unions and environmental activists) in the United States' context and the resilience of capitalism despite this active resistance. She highlighted the strength of corporations and a privileged capitalist elite to influence the regulation of laws that expand their power, which is already vast. As a consequence, even when environmental and labor union movements manage to expand their rights, these rights are disrespected without a strong economic, cultural, and political influence to pressure the authorities (Snider, 2020).

Overall research on corporate crimes originated in the American criminology literature and has focused mainly on crime antecedents and consequences as if they were contingencies, i.e., as dysfunctions of corporate operations rather than something likely to happen in different versions of modern capitalism around the world. Sutherland's (1956) seminal work discussed the common understanding of corporate crime. It coined the term 'white-collar crime' to refer to crimes committed by people of respectability and high social status in the course of their occupation. Since then, a theoretical body that considers corporate crimes as dysfunctional phenomena has emerged. However, this perspective silences and neglects past political, economic, and social struggles against the advance of capitalism.

Research studies have defined corporate crimes concerning their (il)legality. They distinguished terms to argue about the impossibility of charging corporations with a crime. This is because corporations are considered entities. Hence, talking about corporate crime challenges the sense of reality, as criminal laws derive from individual principles, and the laws and punishments imputed to individuals cannot be imputed to corporations (Vining, 2003). The legal systems of different countries react to corporate crime differently. In many countries, the idea that corporations do not commit crimes still prevails. Also, the role of the law is ambiguous concerning corporate damage (Haines \& Macdonald, 2019).

Van Erp and Huisman (2017) defined corporate or organizational crime as "illegal or harmful acts, committed by legitimate organizations or their members, primarily for the benefit of these organizations" (Van Erp \& Huisman, 2017, p. 249). However, Tombs and Whyte (2020) indicated that laws and regulations have conventionalized and normalized several types of corporate crimes, "ensuring that the capital, in the form 
of the corporation, continues to multiply regardless of its damaging effects on the capacity for human life reproduction" (Tombs \& Whyte, 2020, p. 18).

By focusing on diversions from legal regulations, knowledge produced about corporate crimes has undermined debates based on resistance and mobilization in the fight against corporate abuse. This idea is implicit in postcolonial thinking. This perspective has been used to analyze issues involving the context of imperialism, colonialism, and neocolonialism. In other words, postcolonial thinking is a theoretical contribution that can reveal the statements of different versions of capitalism in their forms of domination and expropriation of material and immaterial goods, including control over life.

Our goal is to theoretically challenge the notions of corporate crimes carried out in the traditional literature, which understands this type of crime as an organizational dysfunction, focusing on its antecedents and determining factors. Our basic premise is that this literature understands corporate crimes as dysfunction in organizations. However, they occur within corporations' own dynamics, in which the power of political and economic influence seems to be limitless and supports a destructive version of capitalism. Corporate crimes occur continuously in extremely complex interrelationship contexts, including the relationships between corporations and governments. We aim to explain these crimes from a postcolonial perspective by means of the notions of necrocapitalism.

This essay is structured as follows: we start with an explanation of postcolonialism and provide the notions of corporate crime in the traditional literature. We support our premise based on the postcolonialist perspective and finish our paper with our conclusions.

\section{POSTCOLONIAL THINKING AND THE CONCEPT OF NECROCAPITALISM}

The postcolonial approach takes different directions (Prasad, 2003; Westwood, 2006; Young, 2001). Young (2001) clarifies the semantic differences between the terms postcolonial, postcoloniality, and postcolonialism. The author suggests that the latter is a form of theorized and elaborated criticism to challenge the conditions of postcoloniality. Westwood (2006) stated that "postcolonialism is also variously seen as an analysis of the language and discourse of imperialism, as a recovery of the silenced voice of those marginalized and oppressed through colonialism, or as a critique of the (imposed) notion of the nation state and debunking of the myths of development"(Westwood, 2006, p. 93).

The postcolonial theory addresses a syncretic theoretical production and political positions that foster internal debates, tensions, and heterogeneities within postcolonialism. This theory "creatively employs concepts and epistemological perspectives deriving from a range of scholarly fields ... as well as from multiple approaches to inquiry (e.g., variants of Marxism and neo-Marxism, feminism, psychoanalysis, poststructuralism, deconstruction, 'queer' theory, and so on)" (Prasad, 2003, p. 7).

Postcolonial thinking provides new perspectives on the history of colonialism and the situation of postcolonial societies, placing the criticism of unequal relations between the Global North and the Global South at the center of the debate. The root of this thinking include mainly Indian authors living in the United Kingdom, such as Said (1978), Bhabha (1994), Spivak (1999), as well as authors from peripheral countries, such as Frantz Fanon (1967), Mignolo (2000), Quijano (2000) and Dussel (1995). Despite the break with postcolonial thinking, these authors played a key role in the formation of an anti-colonial consciousness and of the critical discourse of difference from the perspective of colonized people.

Said (1978), for example, developed a criticism about the representation of the 'Other' in the scope of the Western discourse based on the relationship between discourse and power and inspired by Michel Foucault. According to Said (1978), the West painted an image of the East that translates it into the imposition of violence against the 'Other,' who becomes invisible due to the very discourse that names it. Spivak (1994) addressed the silence of colonized subjects not to deny subordinates' voice but rather to show that the place of enunciation they occupy in the colonial relationship is a process of silencing and creating space for colonial discourse.

The discussion about resistance in postcolonial thinking is present in several studies, such as: Bhabha (1994), who starts from the concept of borders as a place of articulation to rethink the concepts of nationalism, representation, and resistance; Said (2003), who sees popular culture as a form of resistance; and Ashcroft, Griffiths and Tiffin (2008), who suggest that transformation is the most appropriate way to achieve the goals of resistance. However, some authors, such as Young (1999), reject resistance as it is conceived in postcolonial studies because this concept undermines the possibilities of active movements that intervene 
in the order to the point of causing social, political, cultural, and economic changes.

When assessing colonialism and neocolonialism, the postcolonial theory places the subjects of the South as agents capable of answering, resisting, and surviving under conditions of violence and cruelty. The notion of discourse in the postcolonial theory enlightens the questions surrounding the exercise of imperial power and the mutual overlapping of the material and the ideological sphere. Mir, Mir and Upadhyaya (2003) locate the ideology of 'reality as a resource' within the 'ideologies of colonizing' and 'ideologies of organizing.' They signal the congruence of the ideological discourses that support both local and organizational life standards. Thus, the discourses that support the capitalist logic sustain the corporate and managerial ideologies, the forms of domination and expropriation of material and immaterial goods, and control over life.

The historical processes that constitute imperialism and colonialism supported the expansion of capitalism because both represent forms of domination, accumulation, and exploitation of territories either informally or formally (Banerjee, 2008). Imperialism and colonialism are used as synonyms, but Banerjee (2008) recognizes some differences between them. For example, colonialism involves the annexation and government of territories, which is not a necessary condition of imperialism.

Nevertheless, Banerjee (2008) states that discussing these differences is unavailing because the focus is on the historical process that constitutes them. Colonialism involves the domination and occupation of physical space, knowledge systems, and the culture of the native inhabitants of a territory (Prasad, 2003). Colonizers integrate native inhabitants into a Western perspective and develop complex relations with them, where colonized subjects depend on the colonizers (Mbembe, 2003). Imperialism, on the other hand, involves the exploitation of the resources of one nation by another alongside the control of the political sovereignty of a territory, through either force, political collaboration, or the creation of economic, social, or cultural dependence (Prasad, 2003).

Imperialism operates through different kinds of power: institutional power (agencies), economic power (corporations and nation states), and discursive power, which "constructs and describes uncontested notions of 'development,' 'backwardness,' 'subsistence economies' while disallowing other narratives from emerging" (Banerjee, 2008, p. 1544).
Banerjee (2008) introduces the term necrocapitalism as a type of contemporary capitalism that subjugates life. This concept was based on Agamben (1995, 2005), who discusses terms such as states of exception and transgression of sovereignty, and on Mbembe (2003), who develops the concept of necropolitics. Necrocapitalism describes specific capitalism practices - marginalized in management literature - as "contemporary forms of organizational accumulation that involve dispossession and the subjugation of life to the power of death" (Banerjee, 2008, p. 1541), such as appropriating "the employees' guarantee fund, overexploiting him/her so intensely that leads him/her to complete exhaustion and death" (Luce, 2013, p. 157).

Taking the notion of necrocapitalism to the context of COVID-19, Jesus (2020) argues that the pandemic has reinforced the division between those who may or may not live, unveiling the lives that are considered expendable. Lawreniuk (2020) argues that the pandemic crisis displayed the tensions and contradictions in the organization of global capitalism even before causing a rupture. It revealed the precariousness of workers in global production networks, which are necrocapitalist infrastructures that optimize consumers' lives by profiting from the exploitation of workers.

Necrocapitalism "emerges from the intersection of necropolitics and necroeconomics as practices of accumulation in (post)colonial contexts by specific economic actors - transnational corporations, for example - that involve dispossession, death, torture, suicide, slavery, destruction of livelihoods, and the general management of violence" (Banerjee, 2008, p. 1546). In this type of capitalism, imperialism is present in institutional structures and processes, which can be analyzed in the relations between nations, international institutions, and transnational corporations. In this situation, sovereignty - the competence of a nation or territory to make decisions - is suspended (Schmitt, 1992): "violence, dispossession, and death that result from practices of accumulation occur in spaces that seem to be immune from legal, juridical, and political intervention where permanent transgressions of sovereignty occur" (Banerjee, 2008, p. 1544).

When conflicts emerge, the state is responsible for solving them, deciding with the intention of undermining the disturbance of the internal order, even if, for that, it must call for a dictatorship or another artifice. However, modern empires intervene in territories beyond their borders: either in political processes, or in the management of the (third) world (Cooke, 2004), or by promoting wars. Wars lead to 
the "inability to tell the difference between combatants and non-combatants" (Hobsbawn, 2010, p. 23), to an increase in the number of civilians killed and injured in war conflicts, to the loss of government authority, to the privatization of the means of war, and to the multiplication of private actors in the international context (Hobsbawn, 2010).

Schmitt's notion of sovereignty refers to the legislative control over a territory and over the body of the other as part of that territory. This unrestricted, arbitrary, and discretionary control enables the annihilation of equivalent attributions in the others and the eradication of their power: "The ultimate expression of sovereignty resides, to a large degree, in the power and the capacity to dictate who may live and who must die" (Mbembe, 2003, p. 11). It is not just about the power of death, which does not consist of sovereignty itself. In its extreme phase, sovereignty 'allows one to live or lets one die;' it dominates life as life fulfills the domination.

By assigning sovereignty the power to decide who may live and who must die - in other words, to kill or to allow to live - Mbembe (2003) introduces politics as 'death that lives a human life.' Necropolitics is the subjugation of life to the power of death, which is the necropower: power decides who dies. Mbembe (2003) discusses necropolitics and necropower to account for how

weapons are deployed in the interest of maximum destruction of persons and the creation of 'deathworlds,' new and unique forms of social existence in which vast populations are subjected to conditions of life conferring upon them the status of 'living dead' (Mbembe, 2003, p. 40).

The relationship between the state of exception and sovereignty results in the authority to kill not only controlled by the state but also distributed by society.

The state of exception consists in creating and ensuring a situation that enables the enforcement of the law, which is possible due to the power of sovereignty (Agamben, 2005). This situation represents a gray area, where one cannot distinguish the political from the legal aspect, the rule from the living subject. As examples of contemporary states of exception, Agamben (2005) mentions the Nazi state and Guantanamo Bay, where violence, torture, and death occurred without any political or legal intervention, as "the state of exception thus creates a zone where the application of the law is suspended but the law remains in force" (Banerjee, 2008, p. 1544). Sovereignty has the power to enforce the state of exception as it invokes the power to decide on the value of life without considering it a homicide. However, the state of exception is not anarchy and chaos, because "an order remains, in a legal sense, even if not a legal order" and "the existence of the state maintains here undoubted supremacy over the validity of the legal norm" (Schmitt, 2006, p. 13).

However, sovereignty has been transgressed (Banerjee, 2008). Despite the notions of independence and supreme authority of nation states, the borders of territories and nations have been transgressed by "imperial formations" - a condition of necrocapitalism - and by colonialism, which represents "a permanent state of exception where sovereignty became an exercise of power outside the law" (Banerjee, 2008, p. 1545). This is where transnational corporations seem to operate with impunity (Pearce \& Tombs, 1999). Besides, the power of colonization allows the display of the power of death to those destined to stay alive. Sovereignty is not only the power of death over the colonized but rather their psychological and moral defeat and their transformation in the audience of the exhibition of the power of death, a physical, psychological, and moral violence.

The transgression of sovereignty in the postcolonial era occurs in the wake of neoliberal policies and of the entanglement of transnational governments, agencies, and corporations that regulate the economy, the market, and the sociocultural system of peripheral territories. Thus, political sovereignty is subservient to the corporate economic sovereignty. In this context, necrocapitalism is characterized by the creation of states of exception where democratic rights are confined to the political sphere, and violence, coercion, and murders occur. Necrocapitalist practices deny people access to resources that are essential to their health and life (Banerjee, 2008).

In this section, we emphasized how postcolonial thinking reveals contemporary capitalist practices that organize their forms of accumulation involving violence, expropriation, and the subjugation of life to the power of death. The next section explores notions of corporate crimes in organizational theories within the current traditional literature.

\section{CORPORATE CRIMES IN THE TRADITIONAL LITERATURE}

Literature attributes the origin of studies on corporate crimes to the concept of 'white-collar crime,' used for the first time by Edwin Sutherland in his presidential speech at the American Society of Sociology in 1939 (Braithwaite, 1989; Strader, 2002). He defined 
white-collar crime as "a crime committed by a person of respectability and high social status in the course of an occupation" (Sutherland, 1949, p. 9).

Clinard (1979), after Sutherland (1940, 1944), carried out the first large-scale study on corporations and their violations of laws. Clinard (1979) conducted empirical research with 582 US corporations. They focused on the analysis of the companies' structures and the context in which illegal activities occurred in 1975 and 1976 . The study presents the following definition:

corporate crime is an organizational crime that occurs in the context of complex and varied sets of structural relationships and interrelationships between boards of directors, executive officers, and managers on one hand, and between the parent corporation, the corporate divisions, and subsidiaries on the other (Clinard, 1979, p. 17).

Braithwaite's (1984) definition of corporate crime includes not only acts that violate criminal laws, but also civil and administrative violations: "the conduct of a corporation, or of employees acting on behalf of a corporation, which is proscribed and punishable by law" (Braithwaite, 1984, p. 6). Several authors have agreed on this definition (Daboub, Rasheed, Priem, \& Gray, 1995). According to them, when corporations engage in morally unacceptable non-provided practices due to the absence of laws on these activities, new laws and regulations may arise to prevent their recurrence. However, the authors have overlooked corporations' ability to influence law enforcement.

Clinard and Quinney (1973) changed the configuration of concepts by categorizing 'whitecollar crimes' into two types: corporate crimes those committed on behalf of the corporation; and occupational crime - those committed against the corporation for self-benefit of an individual. According to these authors, a 'white-collar crime' includes not only crimes committed by the corporation, but also those committed against it, such as occupational crimes, in which usually, but not necessarily, the corporation is the only victim.

The illegality or not of the act is always present in the discussions on corporate crime. Baucus and Dworkin (1991) highlighted that researchers have used the terms 'corporate crime' and 'illegal corporate behavior' interchangeably without explaining their choices. A group of researchers uses corporate crime to talk about any activity that violates criminal law, while others see it as a subset of illegal corporate behavior.
Other authors understand this relationship differently, such as Geis (1991), who sees 'whitecollar crime' as illegal behavior, and Daboub, Rasheed, Priem and Gray (1995), who use the terms 'corporate illegal activity,' 'organizational crime,' and 'corporate wrongdoing' interchangeably. For these authors, what defines illegal corporate activity is the identity of the beneficiary, i.e., whether the act is committed in favor of the corporation or not.

Questioning the use of the two terms, Baucus and Dworkin (1991) presented their distinction, which focuses on the fact that, in the case of corporate crime, "the courts have ruled that the firm committed a criminal act" (Baucus \& Dworkin, 1991, p. 234). Illegal corporate behavior consists in "violations of administrative and civil laws, decided by a variety of procedures such as consents, decrees, settlements, judgments against the company or fines," and it may be intentional or not (Baucus \& Near, 1994, p. 234).

Baucus (1994), Baucus and Dworkin (1991), and Baucus and Near (1994), distinguish both terms according to the criminal court's decision in the case of corporate crime, which is a point of divergence among several authors, including Sutherland. These authors argue that corporate crime is not the same as illegal behavior, and they use three dimensions to differ the two terms: (a) law enforcement and case resolutions differ (decisions are influenced by the merits of the case such as limited budget and lack of information - , the power of the corporation, and whether the regulatory agency should keep or relinquish control over the case), (b) causal factors lead to different types of corporate wrongdoing (e.g., Baucus, 1994; Baucus \& Dworkin, 1991; Baucus \& Near, 1994; Clinard, 1979) and (c) the purposes and consequences of the activities differ.

Kramer's (1984) concept focuses on fundamental questions to define corporate crime: the intentionality or not of corporate crime; whether the corporate and managerial decisions cause the crimes rather than the individual's bad conduct or negligence; and, mainly, the close connection of the crime with benefits obtained for the corporation: "omission or commission criminal acts are the results of actions taken deliberately (or culpable negligence) by executives or managers in the organization's structure" (Kramer, 1984, p. 18). These decisions are based on the organization and are "made following the normative objectives (mainly corporate profit), standard operating procedures, and the cultural norms of organizations - and intend to benefit the corporation itself" (Kramer, 1984, p. 18).

Michalowski and Kramer (2007) proposed the concept 'state-corporate crime,' which differs from the 
traditional concepts of corporate crimes. State-corporate crimes are "illegal or socially harmful actions that occur when one or more institutions of political governance pursue a goal in direct cooperation with one or more institutions of production and economic distribution" (Michalowski \& Kramer, 2007, p. 270). This concept focuses on deviant inter-organizational relationships between business corporations and governments, which act within the capitalist system with harmful consequences.

'State-corporate crimes' occur in two situations: when corporations employed by a government engage in organizational deviance or have government approval to do so; and when regulatory government institutions fail to restrain deviant business practices. For example, the regulatory reversals of Trump's neoliberal agenda facilitate crimes against public health. These reversals weaken or revoke regulations that limit threats to public health, which can encourage companies to engage in harmful practices (Michalowski \& Brown, 2020), and expose the weaknesses of the opposing forces to neoliberal global capitalism (Snider, 2020).

Despite the debates and controversies, the most accepted concept of corporate crime is usually strictly legal, i.e., when the law condemns a company (Mokhiber, 1995). However, this conception of corporate crimes ignores the consequences for the victims and consents that these are inevitable events, accidents; therefore, corporate crimes demand no efforts to enlighten paths to avoid them. This conception ignores that corporate logic — based on the continuous search for better results - makes corporate crimes inevitable.

The fields of legal sociology and criminology inaugurated studies on corporate crimes and received the attention of organizational researchers. These studies were initially developed from an individual approach or at a micro-level analysis, which failed to produce sufficient explanations about the practices committed in the context of corporations (Braithwaite, 1989; Daboub et al., 1995; Gorsira, Steg, Denkers, \& Huisman, 2018; Mon, 2002; Szwajkowski, 1985; Szwajkowski, 1992; Van Akkeren \& Buckby, 2017). A macro approach to corporate crime emerged in the 1960 s and split opinions about research orientation. However, the individual approach was again widely used in the 1990s by several criminologists (Gottfredson \& Hirschi, 1990; Grasmick, Tittle, Bursik, \& Arneklev, 1993; Herbert, Green, \& Larragoite, 1998) who argued that organizations are at the center of opportunities for crimes to occur, but the decision to commit or not commit a crime is up to the individual.
This argument guided research on opportunistic behavior as cause of corporate crimes (Arantes, 2011; Lacerda, Motta, \& Santos, 2019; Van Akkeren \& Buckby, 2017). However, according to Van Erp (2018), "the problem of corporate crime transcends the micro level of the individual 'rotten apple" (Van Erp, 2018, p. 36). The biological and psychological approaches were also insufficient to explain the antecedents of corporate crimes, which demanded a search for interactionist approaches to provide knowledge about how individuals engage in crimes in the corporate context.

Supporters of the macro approach (Benson \& Cullen, 1998; Braithwaite, 1989; Fisse \& Braithwaite, 1993; Vaughan, 2007) emphasize that organizations or groups of individuals commit corporate crimes. Therefore, theories of crime applicable to individuals cannot explain the illegal behavior of corporations; it must be seen as an organizational behavior that reflects institutional forces. Vaughan (2007) argues about the need to go beyond the explanation of corporate crime through a connection between the micro and macro level. This investigation should include organizations as an intermediate level in this process.

To expand the analysis of corporate crime, Vaughan (2007) introduces the meso level, which includes complex and formal organizations and connects the macro level (institutional forces) and the micro level (microprocesses that affect individual decisions and actions). By emphasizing the role that organizations and culture play in mediating macro and micro influences, Vaughan (2007) proposes we analyze corporate crimes considering these three levels so that we understand human behavior (micro level) as an action affected by institutional and organizational forces.

Integrative approaches emerged from the intellectual effort of sociologists and criminologists who, through different paths, resorted to the organizational theory to support their corporate crime analysis, such as Clinard (1983), Clinard and Yeager (1980), Cohen (1977), Finney and Lesieur (1982), Szwajkowski (1985, 1992), Coleman (1987), Baucus and Near (1994), Baucus (1994), Vaughan (2007), Michalowski and Kramer (2007), Gorsira, Steg, Denkers and Huisman (2018), among others. Unlike street crimes, corporate crimes require knowledge of the nature of organizations.

Braithwaite (1989) refutes this aspect. He considers it is a mistake to assume that corporate crimes are so different from individual crimes that they require different paradigms for analysis. Braithwaite (1989) does not refute the fact that theories about organizational crimes derive from organizational theory, but he considers that the integration of two 
important traditions is sufficient to explain corporate crimes: Bonger's Marxist analysis and Sutherland's differential association theory, which explain the crimes of the impotent and the powerful.

The integration of these two perspectives, which Braithwaite (1989) sees as compatible, results in the connection between the theory of opportunity and the theory of subcultures. Opportunities to commit a crime appear when there are obstacles to the legitimate realization of the aspirations and/or objectives valued by society. These aspirations differ according to the groups, resulting in the emergence of subcultures.

By transposing this thinking to corporate criminality, Braithwaite (1989) provides two propositions for a theory of organizational crime: (a) organizational crime occurs when an organization (or a division) faces obstacles to reach its goals through legitimate opportunities, and (b) organizational crime occurs when illegitimate opportunities are available to organizational actors to achieve their goals. Therefore, subcultures transmit knowledge about how different organizational actors can work together to break the law and thus achieve organizational or group goals.

Braithwaite's (1989) propositions are in line with what Needleman and Needleman (1979) affirm about the origin of corporate crimes. These authors agree that, within the context of corporations, we cannot analyze criminal behavior only as a personal deviation; instead, we should think of it as a product of the relationships between members of certain organizational systems. Gorsira et al. (2018) think likewise. They suggest that the crime of corruption is not an isolated process or an individual issue: just as an ethical organizational climate can influence the personal and social norms of employees, the opposite can encourage corruption.

Without referring to the influence of culture, Needleman and Needleman (1979) claimed that corporate crime is a legitimate activity in organizational systems where the economic, legal, organizational, and normative characteristics influence the commitment of crimes, regardless of the degree of personal motivation of the individuals involved.

Needleman and Needleman (1979) acknowledged that a great part of the literature that investigates the origin of corporate crime has focused on systems where organizational structures encourage crimes. The authors described two models of 'criminogenesis' concerning organizations: the first, called 'crimecoercive system,' includes systems that compel their members to commit illegal acts for the benefit of the organization (and indirectly for the benefit of those members); and the second, 'crime-facilitative system,' consists of organizational systems that facilitate and encourage the practice of crime due to their structural conditions, incentives, and opportunities. Contrary to the first model - in which criminal activities are essential to the business - , the second model rejects criminal activities, but they are an inevitable cost to the business. In this direction, Pierce (2015) understands that the fight against corporate crime must begin by eliminating perverse incentives, such as performancebased remuneration, which highlights the functionalist nature of the approach.

Both Braithwaite's (1989) and Needleman and Needleman (1979) propositions indicate the strength of Vaughan (2007) arguments regarding the inclusion of a level of connection between the micro and macro levels for the analysis of crimes within the scope of organizations. Vaughan (2007) disregards the emphasis on organizations and culture as a mediating level of micro and macro influences. She adopts an interactionist perspective in which interaction emerges in socially organized configurations so we cannot see human actions isolated from the social-historical context in which they occur.

Vaughan (2007) relies on three theoretical developments to defend the need to investigate how macro and micro influences are related and understand that human action is situated. The first is the vast literature that debates the relationships between structure and agency (Pierce, 2015). The second is the inclusion of culture as a mediator in these relationships. Culture is the link between an individual's position in a structure and interpretive practices, between meanings and action at the local level, as shown by Lin's (2019) studies in China and Van Rooij and Fine (2018), who speak of a toxic organizational culture.

The third theoretical development refers to two other theories that together strengthen the importance of the role of organizations and culture in the situated action: the new institutionalism (Dimaggio \& Powell, 1991) and the economic action and social structure of Granovetter (1985).

These two theoretical contributions reject determinism from the perspective of rational choice (Dimaggio \& Powell, 1991; Granovetter, 1985) and place organizations at the center of investigations. They lay the grounds to go beyond the macro and micro levels to understand how they are, at the same time, receivers, transmitters, and generators of culture and history. On the one hand, the new institutionalism argues that cultural norms constitute the social actors (state, organizations, occupations, and individuals) that define 
the legitimate objectives to be achieved; therefore, they affect the action and creation of meaning at the local level. On the other hand, Granovetter (1985) explains that economic action is embedded in the structures of social relations, pointing out the relative autonomy and/or dependence between economic action, social action, and the constituted cultural and institutional models, since social contexts influence economic agents (individuals or organizations).

Such theoretical developments direct our attention to the way social life is organized, emphasizing (Vaughan, 2007) the situated character of the individual's behavior. To progress with the analysis based on the articulation of the macro and micro levels to understand human behavior as a situated action, Vaughan (2007) introduces a theoretical elaboration that integrates approaches from organizational theory and theories of crime for the analysis of corporate crime: cultural determination and normalization of deviation. Institutionalized norms and values in society, industry, and organization are causal factors for the occurrence or not of corporate crimes, since institutional and organizational forces limit individuals' choices. From this perspective, culture is an antecedent of corporate crime (Lin, 2019; Macaulay, 2011).

Research that analyzes corporate crimes includes, in general, key factors for their occurrence, which may be interpreted as intentional (deliberate) or by negligence (Grabosky \& Braithwaite, 1987; Payne, 2012). Different levels also guide these approaches to establish hypotheses or theoretical assumptions about these factors, some of which coincide.

It is possible to envision three main theoretical approaches to the study of corporate crime: (a) Sutherland's differential association theory, which regards the individual level of action; (b) organizational theory, which regards the origin of corporate crimes in the search for superior performance, and in the emphasis on corporate goals and operational procedures and standards - so institutional and organizational factors, such as the absence of internal controls, influence the occurrence or not of corporate crime - (Amorim, Cardozo, \& Vicente, 2012; Baucus \& Dworkin, 1991; Baucus \& Near, 1994; Coleman, 1987; Mon, 2002; Ramos, 2010; Silva, Marques, \& Teixeira, 2011; Szwajkowski, 1985); and (c) the political-economic or radical approach, which considers the origin of crime to be related to the political and economic structure of capitalism, whose presence in corporate crimes' studies is still limited. In this perspective, the characteristics of capitalist society interact with the level of organizational and individual action, influencing the occurrence of corporate crime (Michalowski \& Kramer, 2007).

These approaches differ in many aspects. However, the conversation between different paradigms may bring important contributions to the field of study, considering the potential of integrated perspectives for the analysis of a multidisciplinary phenomenon, such as corporate crimes. Michalowski and Kramer (2007) propose an analytical 'framework' to integrate the theory of organizational crime, which links the three levels of analysis (individual, organizational, and institutional) to three catalysts for action, namely: motive or pressure for performance, opportunity structure, and operationality of control. The proposition is that corporate crime results from the combination of pressures to achieve organizational goals, availability, and perceived attractiveness of illegitimate means of acting and lack of effective social control. This excludes the possibility of advancing to broader explanations about the role of corporations as a force of capitalism.

In this section, we showed that the analysis of corporate crime, based on various theoretical models from the traditional literature, seeks to cover as many organizational, institutional, and individual variables as possible. However, although we recognize that the efforts of these authors to integrate the different levels have resulted in relevant contributions to the knowledge about corporate crime, few results go beyond these factors, making the explanations partial and incomplete for a phenomenon caused by corporations, the main force of capitalism.

This section focused on the traditional literature developed on corporate crimes and still prevalent in the field of criminology, despite a solid group of critical criminology researchers engaging in issues related to the crimes of the powerful (Bittle, 2018). Critical scholars who research corporate crimes, such as Tombs and Whyte (2020), have questioned the role of the state in the production and reproduction of corporate crimes, so they argue that these crimes should not be normalized or conventionalized in a capitalist society.

However, despite the growing trend in critical criminology, Bittle (2018) recognizes that the focus of research falls on traditional crimes and not on the perspective that corporate crimes are structural problems originating in our capitalist society. 


\section{CHALLENGING THE CURRENT LITERATURE: CORPORATE CRIMES BEYOND THE LEGAL AND DYSFUNCTIONAL CHARACTER}

In this section, we argued that corporate crimes occur continuously in contexts of complex interrelationships, including relationships between corporations and governments. As we have seen, the literature on corporate crimes sees them as a dysfunctional phenomenon in organizations/corporations, which we have critically examined in this essay, focusing on two central premises of the traditional literature: (a) corporate crimes are defined as deviations or dysfunctions at the individual, organizational, and institutional level, and (b) corporate crimes are defined in terms of their legality, i.e., they are punishable by law. These premises predominate in research and obscure significant issues, leading to the denomination of corporate crimes as accidents or fatalities.

Recent history has shown that corporations are involved in corporate crimes that kill on a large scale, just as genocides do. Let us consider the Bhopal case in India in 1984. It resulted in 3,000 deaths and left more than 50,000 people unable to work (Walters, 2009). In Brazil, in the cities of Bento Rodrigues and Brumadinho, the collapses of Vale's dams have resulted so far in 19 and 254 deaths, respectively. The tobacco industry kills more than 7 million smokers every year. Contemporary slave labor affects 46 million people. The war industry continues to supply weapons for conflicts, producing billions of bullets and millions of increasingly sophisticated weapons and spending more than a trillion dollars on weaponry, while a bullet hits a person every second.

Sklair's (2009) consideration about the emergence of a transnational capitalist class that acts as a global dominant class, supported by the cultural ideology of profit-oriented consumerism, suggests that this class

"works consciously to overshadow the effects of the central crises of global capitalism: (1) the simultaneous establishment of increased poverty and wealth, within and among countries, creating social class polarization, and (2) the crisis of environmental unsustainability of the global capitalist system" (Sklair, 2009, p. 498).

The conceptual challenge we introduce lies in the following questions: Are these events not provided for by law to be considered corporate crimes? Are they dysfunctions of a system that does not operate properly? Are they mass murders or genocides? Genocides are mass murders "committed with intent to destroy, in whole or in part, a national, ethnical, racial, or religious group" (Kelly, 2012, p. 357). While genocide refers to intentionality and quality, mass murder refers to scale and quantity. Genocide is organized destruction, usually caused by the state, which often uses informal groups or militias to deny its responsibility. Groups and militias are trained and armed to perform mass murder plans (Stokes \& Gabriel, 2010) and it occurs with the complicity of corporations (Stel, 2014).

We argue following postcolonial thinking, such as Banerjee (2006, 2008), who speaks of capitalist practices that involve the subjugation of life by the power of death. The contemporary version of capitalism enhances what Scheper-Hughes (1996) called invisible genocide or small wars to refer to "everyday forms of violence and suffering in the third world" (Scheper-Hughes, 1996, p. 889). However, invisible genocides or small wars are not invisible because they are hidden or out of sight, but because even though they are right before our eyes they are difficult to notice since we have naturalized them.

Worldwide clothing brands operate with supplies from Bangladesh due to the competitive prices achieved at the expense of overexploitation of workers and poor infrastructure conditions. The results are tragic. In 2005, more than 100 workers died because of the collapse of a textile factory on the outskirts of Dhaka. In 2006, at least 142 workers died and more than 500 became incapacitated in the collapse of factories in Dhaka and Chittagong. In 2010, a 4-floor building collapsed, resulting in more than 25 deaths. In 2012, 13 people died in the fall of a bridge under construction in Chittagong. In the same year, 110 people died in a fire at a clothing factory in Dakar (Muhammad, 2011).

In 2013, a building that housed a garment factory collapsed after collapse warnings in Bangladesh, resulting in more than 200 deaths and 1,000 people injured. The working conditions in clothing factories that supply major global brands (such as GAP, H\&M, Walmart, Target, Adidas, Benetton, and others) put thousands of workers at risk, even after agreements with companies to do reforms to provide security to workers.

A report prepared by the International Labor Rights Forum, the Worker Rights Consortium, the Clean Clothes Campaign, and the Maquila Solidarity Network indicates that 120,000 workers in the 62 factories that produce items for Walmart lack safe fire escape systems, and that factories that supply clothing to GAP and employ 55,000 people have compromised fire exits. Large international companies failed to pressure the owners of garment factories and did not contribute to pay for the repairs (Rushe, 2016; White, 2017). 
These figures are underestimated and do not include all the cases that occurred in the factories due to the dangerous conditions that workers are subjected to in this industry. Other industries also cause a considerable number of victims, such as electronics manufacturers - producers of cell phones and notebooks -, which use cobalt in the production. This confirms the overexploitation of work described by Marini (2017), who characterizes it as "the intensification of work, the extension of the working day and the expropriation of part of the work needed by the worker to replace his/her workforce" (Marini, 2017, p. 334), a form of exploitation that ignores the value of the workforce.

The dynamics of these events have a strong neoliberal political-ideological influence, which expands the domination of private capital (i.e., powerful global corporations) and increases the exploitation of resources and workers in the South, who are challenged to claim human rights and forced to accept low wages and to work under precarious working conditions. Neoliberal policies, by endorsing these corporate practices, subjugate life and wreck ways of life, which creates states of exception in developing countries, such as in Latin America (Banerjee, 2008), and India, and sets the management of the (third) world (Cooke, 2004) by the Global North.

Transnational corporations from the Global North engage in a network of interdependence with the economies of the South, shaping the terms of global trade, dominating markets, production, and labor (Matos, 2012). Economic relations work within the exploitation of a dependence model that promotes a capitalist mentality in peripheral countries (Marini, 2017). These relations maintain these countries in a continuous dependence (Matos, 2012), while countries of the Global North appropriate their production through transnational corporations (Frank, 1978).

In addition to transnational corporations paying the lowest possible wages for workers in peripheral countries, regulatory agencies in the global system, such as the International Monetary Fund and the World Bank, often demand that governments reduce spending and social rights programs that seek to reduce poverty. Globalization often forces mass migration to slums or areas of high social vulnerability, increasing violence, poverty, and crime (Langman, 2012).

From the perspective of battlefields, Haines and Macdonald (2019) pointed out the criminological ambivalence of laws as essential to control corporate crimes and to facilitate them. In this scenario, where laws operate not only as tools to influence contested rules but also as rules that govern regulatory struggles, the progressive law to control harm to business in the
Global North may be considered a transfer of legal rules in the South.

To attract foreign investments and transnational corporations, peripheral countries offer tax exemptions and reductions and implement flexible labor and environmental laws (Jorgenson, 2012). The political activities of transnational corporations influence how democracies work on economic, labor, health, environment, and security issues (Sklair, 2002), and might be a threat to democracy.

These events illustrate the exclusion that Bauman (2005) called 'wasted lives' through the construction of order, economic progress, and globalization. The author speaks of a 'surplus population' that is a kind of human waste: "lives unworthy of being lived, of victims of order-building projects, their members are not 'legitimate targets' excluded from the protection of the law by order of the sovereign. Instead, they are unintended and unplanned 'collateral casualties' of economic progress" (Bauman, 2005, p. 53). This population is a contingent excluded from the economic progress achieved by capitalism, in a process that a small number of people "is necessary to compose the new work mechanisms, which are generally more dynamic and less robust" (Bauman, 2005, p. 53).

In the same direction, Bauman's (1998) thesis asserts that the Holocaust resulted from the triumph of modern rationality over ethics. The perfection of executions, the fulfillment of orders, the smooth functioning of the Jew's extermination system became the object of the systematic and bureaucratic assessment of the Nazi government.

Two concepts present in the corporate crimes' literature have been developed to oppose the current functionalist concept in the traditional literature: necrocorporation or organizations that kill (Medeiros \& Alcadipani, 2017) and killing organizations (Stokes \& Gabriel, 2010). Necrocorporation describes corporations, transnational or not, that use their discursive-institutional, economic, and ideological power to intervene in society and subjugate life to the power of death' using practices that aim to accumulate and, consequently, put profit and operations above life. This concept is restricted to those corporations that effectively engage in necrocapitalist practices, including corporate crime committed by corporations and benefits they receive from other offenders.

The concept of 'killing organizations' (Stokes \& Gabriel, 2010) includes organizations in the context of genocide, a theme also neglected in the disciplines of management and organizational studies, established on the dark side of organizations, since "corporations 
can be directly or indirectly involved in the business of genocide" (Stokes \& Gabriel, 2010, p. 474) In line with this concept, Stokes and Gabriel (2010) argue that genocide is not just an accidental phenomenon, but also a production planned, organized, and controlled to exterminate a large number of people. For that, resources must be made available, actions must be coordinated, information must be shared and individuals must be motivated to perform various associated tasks.

Even though Stokes and Gabriel (2010) walk on a different ground, they associate genocide with the practices referred to by Mbembe (2003), necropolitics, and by Banerjee (2008), necrocapitalism. They argue that this is not a rare or exceptional phenomenon, given that it can take different forms, such as "depriving communities of their dignity and pride, of the means of maintaining their traditions and practices, and of sustaining their natural environment" (Stokes \& Gabriel, 2010, p. 462). Killing organizations are those involved in large-scale deaths and perform corporate practices that, although not classified as genocides, "lead to dispossession, human rights abuses, environmental plundering, forced movement of people and the destruction of ways of thinking, acting and believing" (Stokes \& Gabriel, 2010, p. 477).

By drawing an analogy between organizations and genocides, Stokes and Gabriel (2010) did not intend to compare the ontological qualities of each element neither the violence experienced by the victims of each one. However, they argue that genocide provides important lessons for organizational theory because it raises central questions about organizations, management, logistics, ethics, power, hierarchy, and resistance, since they involve, in addition to the state and agencies, commercial organizations and corporations. The concern with the fact that corporate crime is or is not provided for in law, that is, with legal guilt, should not obscure scholars in a way that they cannot understand the context in which corporations operate. Researchers should direct greater attention to the complicity between corporations and state actors.

Even though these concepts have inspired us to understand corporate crimes, we believe that it is necessary to go further in the search for how corporations act in the production of death. These concepts reflect broad events and require, for their analysis, a conceptual framework that covers spheres far beyond corporations, such as the different versions of contemporary capitalism and their developments.

\section{CONCLUSIONS}

In the present essay, we challenged traditional notions in the literature around corporate crimes and discussed how contemporary capitalism produces corporate crimes. These crimes are not seen as a corporate dysfunction, but a consequence of the different versions of contemporary capitalism - the definition must exclude the issue of law. We assessed an important issue, although it lacks attention from organizational researchers: corporate crimes produced by modern capitalism are potentially guided by human intent and can result in mass murder. We developed an alternative understanding of corporate crimes that goes beyond the perspective originally developed in the US literature, which requires a different theoretical approach.

Rather than seeing corporate crimes from a functionalist perspective - prevalent in the traditional literature - , we suggest looking at the losses of democratic societies, which originate from the asymmetric dynamics produced by powerful corporations with the participation of the state.

Corporate crimes emerge in corporate operations as part of them and not as something external to them. They are not limited to a dysfunction of the system that operates in the production of goods and services. Instead, they are an inherent part of a version of contemporary capitalism in which lives are wasted and 'worlds of death are created.' Although the current literature sees corporate crime as a result of a combination of pressures to achieve organizational goals, this literature fails to explain the destruction caused by the relationship between the state and corporations, where the state's killing authority is distributed for the society.

Historically, corporations have obtained political power and favoring regulatory laws, have monopolized or mapped markets, and have transformed themselves into powerful institutions through special privileges granted to them. Therefore, the strictly legal definition of corporate crime conceals the destructive character of capitalism. Likewise, the concept of 'state-corporate crime' developed in the literature conceals this issue; it reinforces the neoliberal discourse by stating that it is a crime initiated or facilitated by the state.

This essay presents theoretical contributions to organizational studies. We approached the phenomenon of corporate crime from a new perspective. We used postcolonialism, unlike the critical theories already used, and contrasted it with the traditional literature. Besides, the current essay assessed a known phenomenon in an improved way for the field of organizational studies by providing an opposite view to the narrative that seeks 
to justify colonization processes. Examining corporate crimes considering that they may cause the same results as genocide or mass murder allows us to glimpse the mutual constitution and co-presence of micro and macro phenomena.

Also, our approach of corporate crimes helps to rethink the state's definitions of corporate crime, which should be abandoned and replaced by definitions that take human rights into account, given the ability of corporations to influence the drafting and application of laws according to their interests. Like critical criminology researchers, we consider that arguing against the normalization of corporate crimes is necessary in the field

\section{REFERENCES}

Agamben, G. (1995). Homo sacer: Sovereign power and bare life. Stanford: Stanford University Press.

Agamben, G. (2005). State of exception. Chicago: University of Chicago Press.

Amorim, E. C., Cardozo, M. A., \& Vicente, E. F. R. (2012). Os impactos da implementação de controles internos, auditoria e compliance no combate e prevenção à lavagem de dinheiro no Brasil. Enfoque Reflexão Contábil, 31 (3), 23-35. https://doi.org/10.4025/enfoque.v31i3.15616

Antonio, R. J., \& Bonanno, A. (2012). Roots of capitalism. In G. Ritzer (Ed.), Wiley-Blackwell encyclopedia of globalization. Oxford: Wiley-Blackwell.

Arantes, R. B. (2011). The Federal Police and the Ministério Público. In T. Power, \& M. Taylor (Eds.), Corruption and democracy in Brazil: The struggle for accountability (pp. 184-217). Notre Dame: University of Notre Dame.

Ashcroft, B., Griffiths, G., \& Tiffin, H. (2008). Post-colonial studies: The key concepts. London: Routledge.

Banerjee, S. B. (2006). Live and let die: Colonial sovereignties and the deathworlds of neocapitalism. Borderlands, 5(1). Retrieved from http://www.borderlands.net.au/ vol5no1 2006/baneriee live.htm

Banerjee, S. B. (2008). Necrocaptalism. Organization Studies, 29(12), 1541-1563. https://doi.org/10.1177/0170840607096386 of organizational studies, which is possible by treating them as a dysfunction.

We emphasized how corporate crimes are arranged in a chain of agents, including the state, involving a set of violations that attack nations. This essay also supported efforts to rethink several related issues from a particularly recent perspective in organizational studies. Finally, our approach encouraged us to examine the problematic imposition of theories that celebrate irregularities and deviations as part of a regime that values death more than life, which is a growing area of interest for organizational studies.

Baucus, M. S. (1994). Pressure, opportunity and predisposition: A multivariate model of corporate illegality. Journal of Management, 20(4), 699-721. https://doi.org/10.1016/0149-2063(94)90026-4

Baucus, M. S., \& Dworkin, T.M. (1991). What Is Corporate Crime? It Is Not Illegal Corporate Behavior. Law \& Policy, 13(3), 231-244. https://doi.org/10.1111/j.1467-9930.1991.tb00068.x

Baucus, M. S., \& Near, J. P. (1994). Can illegal corporate behavior be predicted? An event history analysis. The Academy of Management Journal, 34(1), 9-36. https://doi.org/10.2307/256300

Baucus, M. S. (1994). Pressure, opportunity and predisposition: A multivariate model of corporate illegality. Journal of Management. 20(4), 699-721. https://doi.org/10.1016/0149-2063(94)90026-4

Bauman, Z. (1998). Modernidade e holocausto. Rio de Janeiro: Zahar Editores.

Bauman, Z. (2005). Vidas desperdiçadas. Rio de Janeiro: Zahar Editores.

Benson, M. L., \& Cullen, F. T. (1998). Combating corporate crime: Local prosecutors at work. Boston: Northeastern University Press. 
Berle, A. \& Means, G. (1932) The modern corporation and private property. New York: Macmillan.

Bhabha, H. K. (1994). The Location of culture. London: Routledge.

Bittle, S. (2018). Steven bittle on crimes of the powerful. Corporate Crime Reporter, 40(13). Retrieved from https://www. corporatecrimereporter.com/news/200/steven-bittlecrimes-powerful//

Braithwaite, J. (1984). Corporate crime in the pharmaceutical industry. London: Routledge and Kegan Paul.

Braithwaite, J. (1989). Criminological theory and organizational crime. Justice Quarterly, 6(3), 333-358. https://doi.org/10.1080/07418828900090251

Carey JR., C. W. (2011). An Essay from 19th Century U.S. Newspapers. Corporations and Big Business. Retrieved from: https://www.gale.com/binaries/content/assets/gale-us-en/ primary-sources/newsvault/gps newsvault 19thcentury usnewspapers corporations essay.pdf

Chomsky, N. (2005). Chomsky on Anarchism. Edinburgh: AK Press.

Clinard, M. B. (1979). Illegal Corporate Behavior. Washington, D. C.: Department of Justice.

Clinard, M.B. (1983). Corporate ethics and crime: The role of middle management. Beverly Hills: Sage.

Clinard, M. B., \& Yeager, P. C. (1980). Corporate Crime. New York: Free Press.

Clinard, R., \& Quinney, R. (1973). Criminal behavior systems: A typology. New York: Holt, Rinehart \& Winston.

Cohen, A. K. (1977). The concept of criminal organization. British Journal of Criminology, 17(2), 97-111. Retrieved from https://www.jstor.org/stable/23636355

Coleman, J. W. (1987). Toward an integrated theory of white-collar crime. The American Journal of Sociology, 93(2), 406-439. Retrieved from https://www.jstor.org/stable/2779590

Cooke, B. (2004). The managing of third world. Organization, 11(5), 603-629. https://doi.org/10.1177/1350508404044063

Daboub, A. J., Rasheed, A. M. A., Priem, R. L., \& Gray, D. A. (1995). Top management team characteristics and corporate illegal activity. Academy of Management Review, 20(1), 138-170. http://doi.org/10.2307/258890

Dimaggio, P., \& Powell, W. (1991). The new institutionalism in organisational analysis. Chicago: Chicago University Press.

Drucker, P. (1993). The concept of corporation. New Jersey: Transaction Pub.

Dussel, E. (1995). The invention of the Americas. Eclipse of "the other" and the myth of modernity. New York: Continuum Publishing.

Fanon, F. (1967). Black skin, white masks. New York: Grove Press.

Finney, H. C., \& Lesieur, H. R. (1982). A contingency theory of organizational crime. In S. B. Bacharab (Ed.), Research in the Sociology of Organizations (pp. 255-299). Greenwich: JAI.
Fisse, B., \& Braithwaite, J. (1993). Corporations, crime and accountability. New York: Cambridge University Press.

Frank, A.G. (1978). Dependent accumulation and underdevelopment. New York: Palgrave Macmillan.

Geis, G. (1991). White collar crime. What is it? Current Issues in Criminal Justice, 3(1),1-17. https://doi.org/10.1080/10345329.1991.12036504

Gorsira, M., Steg, L., Denkers, A., \& Huisman, W. (2018). Corruption in organizations: Ethical climate and individual motives. Administrative Sciences. 8, 1-19. https://doi.org/10.3390/admsci8010004

Gottfredson, M. R., \& Hirschi, T. (1990) A general theory of crime. Stanford, CA: Stanford University Press.

Grabosky, P., \& Braithwaite, J. (1987). Corporate crime in Australia. Canberra: Australian Institute of Criminology. https://www.aic.gov.au/publications/tandi/tandi5

Granovetter, M. (1985). Economic action and social structure: the problem of embeddedness. American Journal of Sociology, 91(3), 481-510. Retrieved from https://www.jstor.org/stable/2780199

Grasmick, H. G., Tittle, C. R., Bursik, R. J., \& Arneklev, B. J. (1993). Testing the core empirical implication of Gottfredson and Hirschi's general theory of crime. Journal of Research in Crime and Delinquency, 30(1), 5-29. https://doi.org/10.1177/0022427893030001002

Haines, F., \& Macdonald, K. (2019). Grappling with injustice: Corporate crime, multinational business and interrogation of law in context. Theoretical Criminology, O(0), 1-20. https://doi.org/10.1177/1362480619872267

Herbert, C. L., Green, G. S., \& Larragoite, V. (1998). Organizational offending: A comment on reed and yeager. Criminology, 36(4), 867-885. https://doi.org/10.1111/j.1745-9125.1996.tb01211.x

Hobsbawn, E. J. (2010). Globalização, democracia e terrorismo. São Paulo: Cia. das Letras.

Jesus, D. S. V. (2020). Necropolitics and necrocapitalism: The impact of COVID-19 on brazilian creative economy. Modern Economy, 11(6), 1121-1140. https://doi.org/10.4236/me.2020.116082

Jorgenson, A. K. (2012). Climate change. In G. Ritzer (Ed.), Wileyblackwell encyclopedia of globalization. Oxford: WileyBlackwell.

Kelly, M. J. (2012). Prosecuting corporations for genocide under international law. Harvard Law and Policy Review, 6(2), 339-367. Retrieved from https://papers.ssrn.com/sol3/ papers.cfm?abstract $\mathrm{id}=2151510$

Key, T., \& Malnight, T. W. (2010). The influence of the World's Lagerst 100 economic entities. Global Trends. Strategic Dynamics Global Limited. Recuperado de: https://www. globaltrends.com/product/special-report-corporate-cloutdistributed-2012-the-influence-of-the-worlds-largest100-economic-entities/ 
Kramer, R. C. (1984). Corporate criminality: The development of an Idea. In E. Hochstedler (Ed), Corporation as Criminal (pp. 13-37). Beverly Hills: Sage Publications.

Lacerda, L. P., Motta, R. G., \& Santos, N. M. B. F. D. (2019). Uma análisedocrimecorporativodecorrupçáoapartirdateoriados custos de transação. Pensamento \& Realidade, 34(3), 78-91. https://doi.org/10.23925/2237-4418.2019v34i3p78-91

Langman, L. (2012). Oppression. In G. Ritzer (Ed.), WileyBlackwell encyclopedia of globalization. Oxford: WileyBlackwell.

Lawreniuk, S. (2020). Necrocapitalist networks: COVID-19 and the "dark side" of economic geography. Dialogues in Human Geography. https://doi.org/10.1177/2043820620934927

Lin, J. (2019). "Corporate crime control in China: An observation from culture perspective". Journal of Money Laundering Control, 22(3), 472-479. https://doi.org/10.1108/JMLC-09-2018-0058

Lord, N., Wingerde, K.V., \& Campbell, L. (2018). Organising the monies of corporate financial crimes via organisational structures: Ostensible legitimacy, effective anonymity, and third-party facilitation. Administrative Sciences, 8(2), 1-17. https://doi.org/10.3390/admsci8020017

Luce, M. S. (2013). A superexploração da força de trabalho no Brasil: Evidências da história recente. In N. Almeida Filho (Org), Desenvolvimento e dependência: Cátedra Ruy Mauro Marini (pp. 145-166). Brasília, D. F.: Ipea.

Macaulay, F. (2011). Federalism and state criminal Justice systems. In T. Power, \& M. Taylor (Eds.), Corruption and democracy in Brazil: The struggle for accountability (pp. 218-249). Notre Dame: University of Notre Dame Press.

Marini, R. M. (2017). A dialética da dependência. Germinal: Marxismo e Educação em Debate, 9(3), 325-356. https://doi.org/10.9771/gmed.v9i3.24648

Matos, C. (2012). Mass Media. In G. Ritzer (Ed.), Wiley-Blackwell encyclopedia of globalization. Oxford: Wiley-Blackwell.

Mbembe, A. (2003). Necropolitics. Public Culture, 15(1), 11-40. Retrieved from https://muse.jhu.edu/article/39984/summary

Medeiros, C. R. O., \& Alcadipani, R. (2017). Organizaçôes que matam: Uma reflexão a respeito de crimes corporativos. Organizaçôes \& Sociedade, 24(80), 39-52. https://doi.org/10.1590/1984-9230802

Michalowski, R. J., \& Kramer, R. C. (2007). State-corporate crime and criminological inquiry. In: H. N. Pontell, \& G. L. Geis (Eds.), International handbook of white-collar and corporate crime. (Cap. 2, pp. 200-219). New York: Springer.

Michalowski,R., \&Brown,M.(2020).Poisoningforprofit:Regulatory rollbacks, public health, and state-facilitated corporate crime. Journal of White Collar and Corporate Crime, 1(2), 113-122. https://doi.org/10.1177/2631309X20919694

Mignolo, W. D. (2000). Local histories, global designs. Coloniality, subaltern knowledges, and border thinking. Princeton, NJ: Princeton University Press.
Mir, R. A., Mir, A., \& Upadhyaya, P. (2003). Toward a postcolonial reading of organizational control. In A. Prasad. Postcolonial theory and organizational analysis: A critical reader (pp. 4776). New York: Palgrave Macmillan.

Mokhiber, R. (1995). Crimes corporativos. São Paulo: Scritta, Página Aberta.

Mon, W. (2002). Causal factors of corporate crime in Taiwan: Qualitative and quantitative findings. International Journal of Offender therapy and Comparative Criminology, 46(2), 183-205. https://doi.org/10.1177/0306624X02462005

Muhammad, A. (2011). Wealth and deprivation: Readymade garments industry in Bangladesh. Economic \& Political Weekly, 20(34), 23-28. Retrieved from https://www.jstor.org/stable/23017787

Needleman, M. L., \& Needleman, C. (1979). Organizational crime: Two models of criminogenesis. The Sociological Quarterly, 20(4), 517-528. Retrieved from https://www.jstor.org/stable/4106061

Payne, B. K. (2012). White-collar crime. The essentials. Georgia: Sage Publications.

Pearce, F., \& Tombs, S. (1999). Toxic capitalism: Corporate crime and the chemical industry. Toronto: Canadian Scholars Press.

Pierce, J. R. (2015). Reexamining the cost of corporate criminal prosecutions. Journal of Management, 44(3), 892918. https://doi.org/10.1177/0149206315594845

Prasad, A. (2003). Postcolonial theory and organizational analysis: $A$ critical reader. New York: Palgrave Macmillan.

Quijano, A. (2000). Coloniality of Power, Eurocentrism, and Latin America. Neplanta: Views from South. 1(3), 533-580. http://dx.doi.org/10.36428/revistadacgu.v5i8.278

Ramos, P. R. A. (2010). Corrupção na Administração Pública e crimes de 'lavagem' ou ocultaçáo de bens, direitos e valores. Revista Mineira de Contabilidade, 4(40), 14-22. Retrieved from https://revista.crcmg.org.br/index.php?journal $=$ rmc\&page $=$ article \&op $=$ view \&path $\% 5 B \%$ 5D=338\&path\%5B\%5D=146

Rushe, D. (2016, december 24). Bangladesh: a etiqueta da tragédia. The Guardian. Retrieved from https://www.theguardian. com/world $/ 2016 /$ nov $/ 21 /$ bangladesh-garment-factoriessafety-alliance-rana-plaza-report

Said, E. W. (1978). Orientalism. London: Routledge \& Kegan Paul.

Said, E. W. (2003). Culture and resistance. Conversations with Edward Said. Cambridge: South and Press.

Scheper-Hughes, N. (1996). Small wars and invisible genocides. Social Science \& Medicine 43(5), 889-900. https://doi.org/10.1016/0277-9536(96)00152-9

Schmitt, C. (1992). O Conceito do Político. Petrópolis: Vozes.

Schmitt, C. (2006). Teologia Política. Belo Horizonte: Del Rey. 
Silva, J. L. R., Marques, L. F. B., \& Teixeira, R. (2011). Prevenção à lavagem de dinheiro em instituiçóes financeiras: Avaliação do grau de aderência aos controles internos. BASE - Revista de Administração e Contabilidade da UNISINOS, 8(4), 300-310. https://doi.org/10.4013/base.2011.84.03

Sklair, L. (2002). Democracy and the transnational capitalist class. International Political Science Review, 23(2), 159-174. https://doi.org/10.1177/000271620258100113

Sklair, L. (2009). The transnational capitalist class: Theory and empirical research. In F. Sattler \& C. Boyer (Eds.), European economic elites: Between a new spirit of capitalism and the erosion of state socialism (pp. 497-524). Berlin: Duncker \& Humblot.

Sklair, L. (2012a). Transnational Capitalist Class. In G. Ritzer (Ed.), The Wiley-Blackwell encyclopedia of globalization. New York: John Wiley \& Sons.

Sklair, L. (2012b) 'Culture-Ideology of Consumerism'. In G. Ritzer (Ed.), Wiley-Blackwell encyclopedia of globalization. New York: John Wiley \& Sons.

Snider, L. (2020). Beyond Trump: Neoliberal capitalism and the abolition of corporate crime. Journal of White Collar and Corporate Crime, 1(2), 8694. https://doi.org/10.1177/2631309X20920837

Spivak, G. (1994). Can the subaltern speak? In P Williams, \& L. Chrisman (Ed)., Colonial discourse and postcolonial theory: $A$ reader (pp. 66-111). New York: Columbia University Press.

Spivak, G. C. (1999). A Critique of postcolonial reason. Toward a history of the vanishing present. Cambridge: Harvard University Press. https://doi.org/10.2307/j.ctvjsf541

Stel, N. (2014). Business in genocide: Understanding the how and why of corporate complicity in genocides. In Maastricht School of Management. Working Paper n. 2014/28, 5 September 2014. Retrieved from http://web2.msm.nl/RePEc/msm/ wpaper/MSM-WP2014-28.pdf

Stokes, P., \& Gabriel, Y. (2010) Engaging with genocide: The challenge for organization and management studies. Organization, 17(4), 461-480. https://doi.org/10.1177/1350508409353198

Strader, J. K. (2002). Introduction to white collar crime. In J. K. Strader. Understanding white collar crime. (Cap. 1, pp. 1-13). New York: LexisNexis.

Sutherland, E. H. (1940). White-collar criminality. American Sociological Review, 5(1), 1-12. https://doi.org/10.2307/2083937

Sutherland, E. H. (1944). Is "White collar crime" Crime? American Sociological Review, 10(2), Annual Meeting Papers (1945 April), 132-139. http://faculty.washington.edu/matsueda/ courses/371/Readings/White\%20Collar\%20Crime.pdf

Sutherland, E. H. (1949) White-collar crime. New York: Holt, Rinehart \& Winston.
Sutherland, E. H. (1956) Crime of corporations. In A. K. Cohen, A. Lindesmith, K. Schuessler (Ed.), The Sutherland Papers (pp. 78-96). Bloomington: Indiana University Press.

Szwajkowski, E. (1985). Organizational illegality: Theoretical integration and illustrative application. The Academy of Management Review, 10(3), 558-567. https://doi. org/10.2307/258136

Szwajkowski, E. (1992). Accounting for organizational misconduct. Journal of Business Ethics, 11(5-6), 401-411. https://doi.org/10.1007/BF00870552

Tombs, S., \&Whyte, D. (2020). The shifting imaginaries of corporate crime. Journal of White Collar and Corporate Crime, 1(1), 16-23. https://doi.org/10.1177/2631309X19882641

Van Akkeren, J., \& Buckby, S. (2017). Perceptions on the causes of individual and fraudulent co-offending: Views of forensic accountants. Journal of Business Ethics, 146, 383-404. https://doi.org/10.1007/s10551-015-2881-0

Van Erp, J. (2018). The organization of corporate crime: Introduction to Special Issue of Administrative Sciences. Administrative Sciences, 8(3), 1-12. https://www.mdpi.com/2076-3387/8/3/36

Van Erp, J., \& Huisman. W. (2017). Corporate Crime. In A. Brisman, E. Carrabine, \& N. South (Ed.), Routledge companion to criminological theory and concepts (pp. 248252). Abingdon: Routledge.

Van Rooij, B., \& Fine, A. (2018). Toxic corporate culture: Assessing organizational processes of deviancy. Administrative Science, 8(3),1-38. https://doi.org/10.3390/admsci8030023

Vaughan, D. (2007) Beyond macro- and micro-levels of analysis, organizations, and the cultural fix. In H. N. Pontell, \& G. L. Geis (Eds.), International handbook of white-collar and corporate crime (Cap. 1, pp. 3-23). New York: Springer.

Vining, J. (2003). Corporate crime and the religious sensibility. Punishment \& Society, 5(3), 313-325. https://doi.org/10.1177/1462474503005003005

Walters, R. (2009). Bhopal, corporate crime and harms on the powerfull. Global Social Policy. 9(3), 324-327. https://doi.org/10.1177/14680181090090030205

Westwood, R. (2006). International business and management studies as an orientalist discourse: A postcolonial critique. Critical Perspectives on International Business, 2(2), 91-113. https://doi.org/10.1108/17422040610661280

White, G. B. (2017 May 3). What's changed since more than 1,110 people died in bangladesh's factory collapse? The Atlantic. Retrieved from https://www.theatlantic.com/business/ archive/2017/05/rana-plaza-four-years-later/525252/

Young, R. J. C. (1999). Ideologies of the postcolonial. Interventions, 1(1), 4-8. https://doi.org/10.1080/13698019800510021

Young, R. J. C. (2001). Postcolonialism: An historical introduction. Oxford: Wiley-Blackwell. 


\section{Authorship}

\section{Cintia Rodrigues de Oliveira*}

Universidade Federal de Uberlândia, Faculdade de Gestáo e Negócios

Av. João Naves de Ávila, no 2121, Santa Mônica, 38400-902, Uberlândia, MG, Brazil.

E-mail address: cintia@ufu.br

(D) https://orcid.org/0000-0001-7999-9002

\section{Rafael Alcadipani da Silveira}

Fundação Getulio Vargas, Escola de Administração de Empresas de Sao Paulo

Rua Itapeva, no 432, Bela Vista, 01332-000, São Paulo, SP, Brazil. E-mail address: rafael.alcadipani@fgv.br

(D) https://orcid.org/0000-0001-5132-5380

* Corresponding Author

\section{Funding}

The authors would like to thank the brazilian Ministério da Ciência, Tecnologia e Inovação, Conselho Nacional de Desenvolvimento Científico e Tecnológico (CNPq), \#309943/2018-3 and \#438742/2018-4 for the financial support.

\section{Conflict of Interests}

The authors have stated that there is no conflict of interest.

\section{Plagiarism Check}

The RAC maintains the practice of submitting all documents approved for publication to the plagiarism check, using specific tools, e.g.: iThenticate.

\section{Authors' Contributions}

$1^{\text {st }}$ author: conceptualization (equal); formal analysis (equal); methodology (equal); visualization (equal); writing-original draft (equal); writing-review $\&$ editing (equal).

$2^{\text {nd }}$ author: conceptualization (equal); data curation (equal); formal analysis (equal); funding acquisition (equal); investigation (equal); methodology (equal); project administration (equal); resources (equal); software (equal); supervision (equal); validation (equal); visualization (equal); writing-original draft (equal); writing-review \& editing (equal).

\section{Copyrights}

RAC owns the copyright to this content.

\section{Peer Review Method}

This content was evaluated using the double-blind peer review process. The disclosure of the reviewers' information on the first page, as well as the Peer Review Report, is made only after concluding the evaluation process, and with the voluntary consent of the respective reviewers and authors.

\section{Data Availability}

RAC encourages data sharing but, in compliance with ethical principles, it does not demand the disclosure of any means of identifying research subjects, preserving the privacy of research subjects. The practice of open data is to enable the reproducibility of results, and to ensure the unrestricted transparency of the results of the published research, without requiring the identity of research subjects. 